\title{
Rancang Bangun Sistem Pemadam Kebakaran Box Panel Outdoor Menggunakan Arduino Uno Berbasis GSM SIM800L V1
}

\author{
Lanina Milenise Fisabili'; Tri Wahyu Oktaviana Putri ${ }^{2}$ \\ 1,2Institut Teknologi PLN \\ ${ }^{1}$ lanina1711280@itpln.ac.id
}

\begin{abstract}
With the installation of electrical installations on the panel box, there is a risk of interference causing fires caused by electricity due to short circuits, burning cables due to poor insulators and MCBs being burned due to overload. So we need a fire extinguishing system on the panel box that can minimize the risk of a large fire and can be monitored remotely. The extinguishing system consists of Arduino Uno as a microcontroller to process data, Infrared sensor KY-026 and temperature sensor DS18B20 as input to detect fire and excess temperature in the box panel. The MG995 Servo Motor and buzzer are used as outputs for the APAR drive and provide early warning. GSM SIM800L V1 as a remote communication to provide notifications to cell phones when fires and excessive temperatures occur. The test results in this study is a fire extinguishing system with $\mathrm{KY}-026$ Infrared sensor which is able to detect fire at an angle of $60^{\circ}$. The DS18B20 temperature sensor detects a temperature of $41^{\circ} \mathrm{C}$ indicating overheating, as well as the MG995 Servo Motor rotates $90^{\circ}$ and the buzzer sounds an alarm then the GSM SIM800L V1 sends a notification remotely which is 1210 meters or even more.
\end{abstract}

Keywords: Fire, Arduino Uno, GSM SIM800L, Infrared KY-026, DS18B20

\begin{abstract}
ABSTRAK
Dengan adanya pemasangan instalasi listrik pada box panel memungkinkan resiko terjadi gangguan yang mengakibatkan kebakaran disebabkan oleh listrik karena hubung singkat, kabel-kabel terbakar karena isolator kurang bagus dan MCB yang terbakar karena kelebihan beban. Sehingga diperlukan sistem pemadam pada box panel yang dapat meminimalisir resiko terjadinya kebakaran besar dan dapat dipantau dari jarak jauh. Sistem pemadam terdiri dari Arduino Uno sebagai mikrokontroler untuk mengolah data, sensor Inframerah KY-026 dan sensor suhu DS18B20 sebagai masukan untuk mendeteksi adanya api dan suhu berlebih didalam box panel. Motor Servo MG995 dan buzzer digunakan sebagai keluaran untuk penggerak APAR dan memberikan peringatan dini. GSM SIM800L $V 1$ sebagai komunikasi jarak jauh untuk memberikan notifikasi kepada telepon seluler saat kebakaran dan suhu berlebih terjadi. Hasil pengujian pada penelitian adalah sistem pemadam dengan sensor Inframerah KY-026 yang mampu mendeteksi api pada sudut $60^{\circ}$. Sensor suhu DS18B20 mendeteksi suhu $41^{\circ} \mathrm{C}$ menandakan overheat, begitu pula dengan Motor Servo MG995 berputar $90^{\circ}$ dan buzzer membunyikan alarm kemudian GSM SIM800L V1 mengirimkan notifikasi secara jarak jauh yaitu 1210 meter bahkan melebihi.
\end{abstract}

Kata Kunci: Kebakaran, Arduino Uno, GSM SIM800L, Inframerah KY-026, DS18B20 


\section{PENDAHULUAN}

Instalasi listrik merupakan sebagian besar komponen-komponen kelistrikan yang disusun dan dirancang untuk dapat menyalurkan instalasi listrik sesuai dengan kebutuhan pemakaiannya. Penggunaan instalasi listrik sebagai penyaluran listrik yang melibatkan komponen-komponen pembantu dan beberapa alat elektronika lainnya untuk mendukung proses penyaluran dan memungkinkan pemasangan instalasinya diklasifikasikan berdasar peletakan yaitu di dalam ruangan dan di luar ruangan. Sehingga pemasangan instalasi memerlukan wadah untuk melindungi komponen yang akan digunakan, maka dari itu digunakan box panel.

Box panel adalah tempat atau wadah untuk melindungi komponen-komponen kelistrikan dari kemungkinan resiko bahaya yang terjadi kemudian box panel memiliki bahan dan ukuran agar bisa disesuaikan dengan kebutuhan instalasi. Dengan instalasi yang disimpan didalam box panel maka akan meminimalisir gangguan listrik yang akan terjadi. box panel juga berperan sebagai pengaman instalasi listrik yang membutuhkan pemasangan diluar lapangan

Dengan adanya pemasangan instalasi listrik maka dari itu memungkinkan resiko terjadi gangguan yang mengakibatkan kebakaran, adapun kebakaran yang terjadi pada box panel disebabkan oleh arus lebih dan hubung singkat maupun kabel yang sudah tidak layak dipakai yang terdapat pada box panel listrik. Adapun tujuan penelitian ialah Membuat suatu sistem rancang bangun pada box panel yang dapat meminimalisir resiko terjadinya kebakaran besar, mengetahui cara kerja komponen-komponen yang digunakan pada sistem pemadam kebakaran box panel, mengetahui keandalan sistem pemadam kebakaran box panel berbasis SMS (Short Message Service).

Dari permasalahan tersebut dibutuhkan suatu sistem rancang bangun pada box panel yang dapat meminimalisasi resiko terjadinya kebakaran besar. Penelitian dengan topik yang serupa telah dilakukan oleh [2] dengan judul "Alat Pencegah Kebakaran Berbasis Mikrokontroler AT89S51 Pada Box Panel Kontrol Listrik" menjelaskan bahwa penelitian yang dilakukan memerlukan pembaharuan penggunaan komponen seperti sensor LM35 sebagai sensor suhu yang kurang sensitif untuk mendeteksi dan LDR sebagai pendeteksi api yang jarak pendeteksinya kurang meluas serta penggunaan sirine sebagai peringatan dini. Sedangkan penelitian yang dilakukan oleh [1] menggunakan sensor Inframerah sebagai pendeteksi api dan sensor suhu DHT11 sebagai pendeteksi suhu dengan komunikasi visual basic. Penggunaan sensor suhu juga dikembangkan untuk pemadam api pada kebakaran hutan [3], ruang kelas [4]. Sementara itu, pada penelitian ini menggunakan sensor Inframerah KY-026 dan sensor suhu DS18B20 yang akan mendeteksi keberadaan api serta suhu didalam box panel sehingga dapat dipantau berapakah rentang suhu berbahaya. Kemudian pemantauan yang dilakukan dapat melalui media jarak jauh yaitu menggunakan GSM SIM800L V1 dengan memanfaatkan telepon seluler sebagai perantara komunikasi pada fitur pesan atau SMS. Penggunaan SMS untuk sistem pemadam kebakaran telah berhasil dilakukan pada penelitian oleh [5], [6], [7]. SMS dipilih karena menjangkau lebih banyak area dibandingkan sistem komunikasi lainnya, 


\section{METODE/PERANCANGAN PENELITIAN}

\subsection{Metode Penelitian}

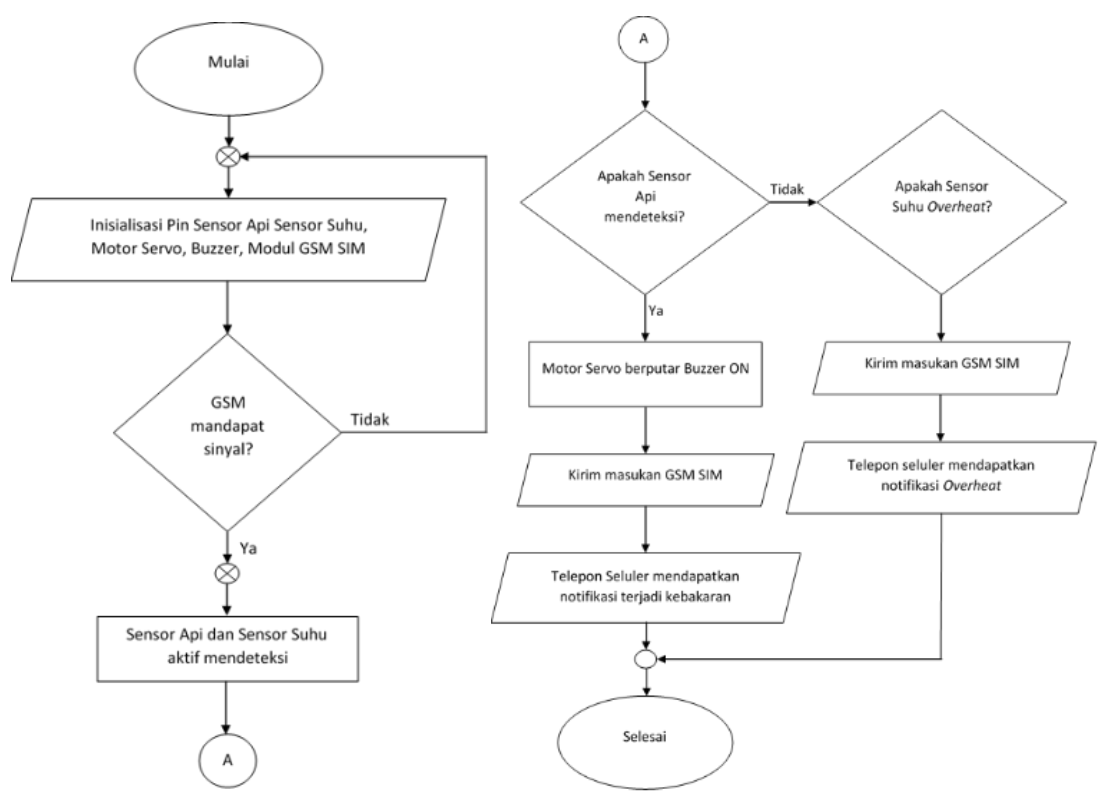

Gambar 1. Flowchart Penelitian

Diagram alir diatas guna penggambaran alur kerja dari sistem yaitu menginisialisasi sensor api, sensor suhu, motor servo, buzzer dan modul GSM SIM kemudian GSM akan mencari sinyal terlebih dahulu agar sistem dapat bekerja dengan benar. Sensor api dan sensor suhu aktif mendeteksi, ketika sensor api mendeteksi maka motor servo dan buzzer on lalu memerintah GSM untuk mengirim pesan ke telepon seluler. Apabila tidak terdapat api, maka sensor suhu akan mendeteksi batas suhu overheat. Ketika suhu terdeteksi overheat maka akan memerintahkan GSM untuk mengirim pesan ke telepon seluler.

\subsection{Perancangan Penelitian}

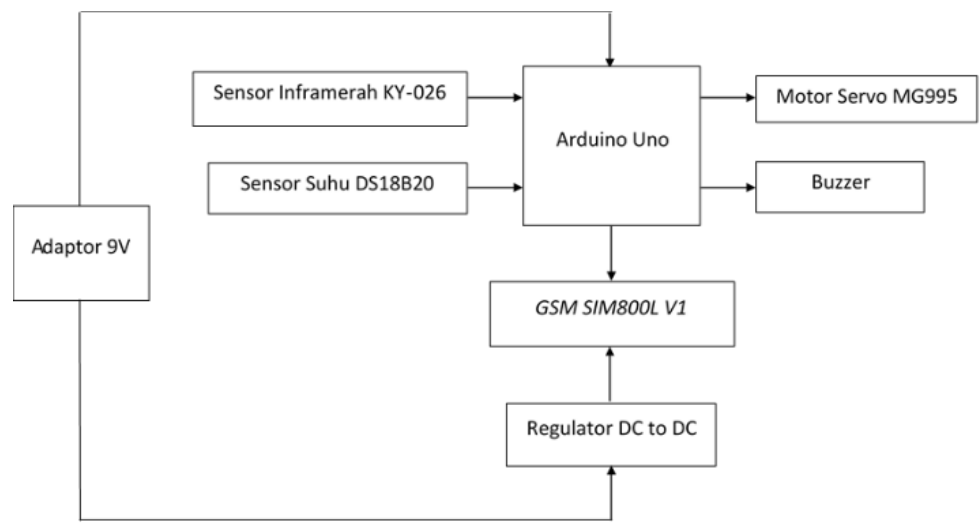

Gambar 2. Blok Diagram Perancangan Perangkat Keras

Adapun inti dari sistem penelitian yang dijelaskan pada blok diagram ialah diberikan sumber pada Arduino Uno dan Regulator melalui Adaptor 9V. Kemudian masukan data dari sensor inframerah dan sensor suhu akan diproses oleh mikrokontroler Arduino Uno dan 
menjalankan tugasnya, ketika Inframerah KY-026 mendeteksi api maka keluaran MG995 akan berputar dan buzzer menyala serta bersamaan dengan GSM SIM800L yang diberikan perintah untuk mengirim pesan ke telepon seluler. Untuk sensor DS18B20 akan mendeteksi suhu overheat kemudian diproses oleh mikrokontroler dan memerintahkan GSM SIM800L mengirim pesan ke telepon seluler.

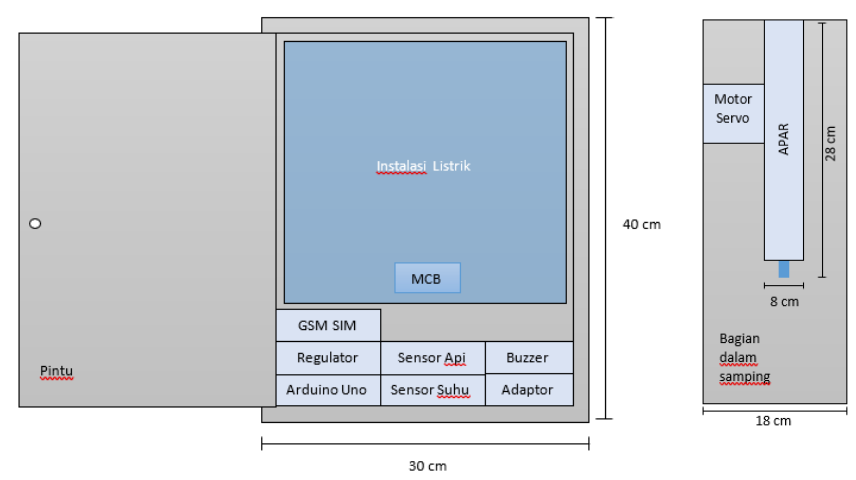

Gambar 3. Ilustrasi Peletakan Komponen

Pada penelitian "Rancang Bangun Sistem Pemadam Kebakaran Box Panel OUTDOOR Menggunakan Arduin Uno Berbasis GSM 800L V1" memerlukan beberapa komponen untuk mengoperasikan fungsi dari alat. Peletakan sensor suhu dan api ditempatkan pada posisi sering terjadi kebakaran serta APAR untuk meredakan api sedangkan letak beberapa komponen lainnya menyesuaikan posisi dari Arduino Uno

\section{HASIL DAN PEMBAHASAN}

\subsection{Pengujian Sensor Inframerah KY-026}

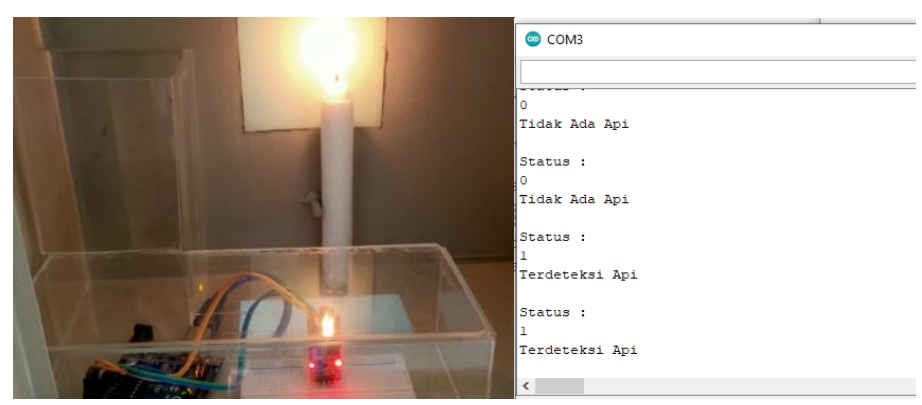

Gambar 4. Pengujian Sensor Infrramerah KY-026

Pengujian dilakukan dengan melihat kondisi sinyal yang terdeteksi melalui LED pada sensor Inframerah KY-026. Terlihat bahwa status keterangan yang didapatkan pada serial monitor sesuai dengan perintah dari Arduino Uno dengan sensor Inframerah KY-026. Sensor memiliki 2 LED untuk menandakan bahwa sensor mendapatkan tegangan dan aktif mendeteksi cahaya yang terpapar dari lilin percobaan. LED pertama akan menyala ketika sensor mendapatkan tegangan sedangkan LED kedua menyala ketika sensor aktif mendeteksi cahaya api. Maka dari itu terlihat pada gambar 4 bahwa kedua LED menyala. 
Untuk menguji posisi api yang berada didalam box panel maka dilakukan pengujian ke beberapa titik di dalam box panel untuk mengetahui sudut deteksi sensor, yaitu :

Tabel 1. Hasil Pengujian Sensor Infrramerah KY-026

\begin{tabular}{|c|c|c|c|c|c|}
\hline No. & $\begin{array}{l}\text { Sudut } \\
\left({ }^{\circ}\right)\end{array}$ & Jarak $(\mathrm{cm})$ & Posisi & Kondisi & Status \\
\hline 1. & $90^{\circ}$ & $15 \mathrm{~cm}$ & Tengah box panel & $\mathrm{HIGH}$ & 1 \\
\hline 2. & $160^{\circ}$ & $10 \mathrm{~cm}$ & $\begin{array}{c}\text { Kanan bawah box } \\
\text { panel }\end{array}$ & $\mathrm{HIGH}$ & 1 \\
\hline 3. & $20^{\circ}$ & $10 \mathrm{~cm}$ & Kiri bawah box panel & $\mathrm{HIGH}$ & 1 \\
\hline 4. & $110^{\circ}$ & $34 \mathrm{~cm}$ & $\begin{array}{c}\text { Kanan atas box } \\
\text { panel }\end{array}$ & $\mathrm{HIGH}$ & 1 \\
\hline 5. & $70^{\circ}$ & $34 \mathrm{~cm}$ & $\begin{array}{l}\text { Kanan bawah box } \\
\text { panel }\end{array}$ & $\mathrm{HIGH}$ & 1 \\
\hline
\end{tabular}

\subsection{Pengujian Sensor Suhu DS18B20}

Pengujian dilakukan untuk suhu ruangan yang berada pada box panel dengan menggunakan api dari lilin. Sensor ini membutuhkan resistor pull-up sebesar 4,7K Ohm, pull-up berguna untuk mencegah nilai float pada kondisi HIGH dengan menambahkan sebuah resistor di jalur sumber tegangan dan parallel dengan jalur input Arduino Uno.

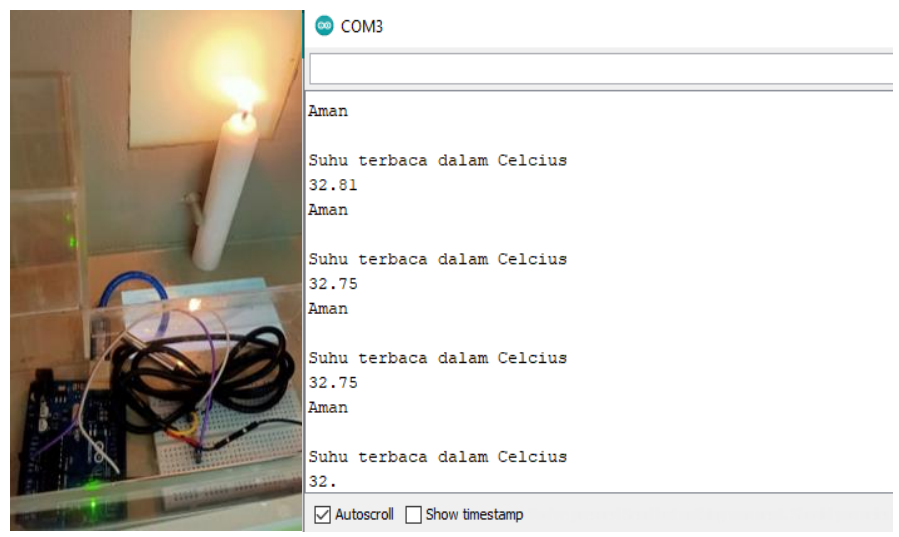

Gambar 5. Pengujian Sensor Suhu DS18B20

Tabel 2. Hasil Pengujian Sensor Suhu DS18B20

\begin{tabular}{|c|c|c|c|}
\hline No. & $\begin{array}{c}\text { Suhu Ruangan Didalam Box } \\
\text { Panel Saat Tidak ada Api } \\
\left({ }^{\circ} \mathrm{C}\right)\end{array}$ & $\begin{array}{c}\text { Suhu Ruangan Didalam Box } \\
\text { Panel Saat Tidak ada Api }\left(^{\circ} \mathrm{C}\right)\end{array}$ & $\begin{array}{c}\text { Waktu } \\
\text { (menit) }\end{array}$ \\
\hline 1. & $41,88^{\circ} \mathrm{C}$ & $36,38^{\circ} \mathrm{C}$ & 15 menit \\
\hline 2. & $43,13^{\circ} \mathrm{C}$ & $37,19^{\circ} \mathrm{C}$ & 45 menit \\
\hline 3. & $46,75^{\circ} \mathrm{C}$ & $39,25^{\circ} \mathrm{C}$ & 75 menit \\
\hline
\end{tabular}

Pada tabel 2 menunjukan bahwa suhu yang terdeteksi berbeda selama setiap 15 menit. Nilai suhu yang digunakan sebagai acuan terjadinya overheat ialah pada titik $41^{\circ} \mathrm{C}$ yang menandakan suhu didalam box panel berlebih dan memiliki resiko terdapat api didalamnya. 


\subsection{Pengujian Motor Servo MG995 dan Buzzer}

Ketika api terdeteksi oleh sensor Inframerah KY-026 maka Motor Servo MG995 akan bergerak dan mengeluarkan cairan APAR. Setelah dilakukan pengujian bahwa Motor Servo MG995 memanfaatkan fungsi motor listrik, dengan torsi yang semakin besar maka kerja dari motor semakin besar. Dengan menggunakan sudut rotasi, Motor Servo MG995 yang sudah dipasang tali dari APAR akan tertarik sesuai putaran sudut yaitu 90 kemudian menekan APAR lalu mengeluarkan cairan pemadam api kebakaran. Sedangkan Buzzer digunakan sebagai peringatan dini pada sekitar lingkungan terdekat dengan box panel.

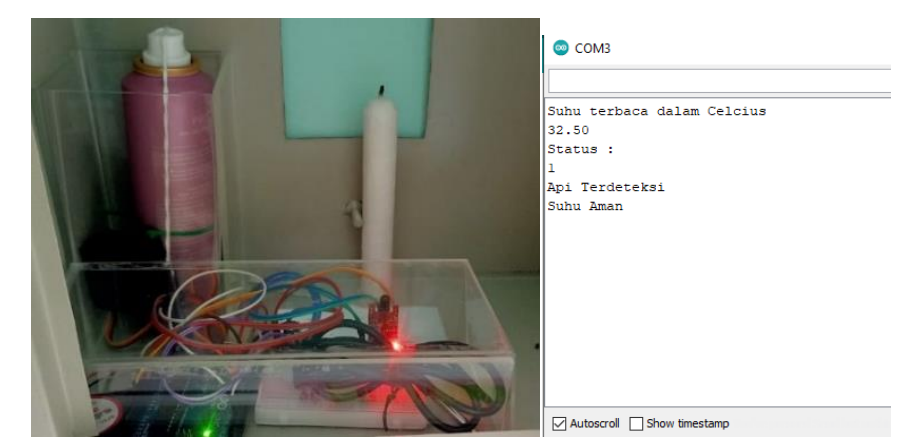

Gambar 6. Pengujian Motor Servo MG995 dan Buzzer

Pada gambar diatas terlihat bahwa perbedaan masing-masing komponen output setelah mendapatkan sinyal dari input. Motor Servo akan bergerak $90^{\circ}$ untuk menekan APAR yang nantinya mematikan api dideteksi oleh sensor Inframerah KY-026 juga buzzer yang aktif berbunyi.

Tabel 3. Hasil Pengujian Motor Servo MG995 dan Buzzer

\begin{tabular}{|c|c|c|c|c|c|}
\hline No. & $\begin{array}{c}\text { Kondisi } \\
\text { Inframerah KY- } \\
026\end{array}$ & $\begin{array}{c}\text { Nilai sensor } \\
\text { suhu DS18B20 } \\
\left({ }^{\circ} \mathrm{C}\right)\end{array}$ & $\begin{array}{c}\text { Waktu suhu } \\
\text { mendeteksi } \\
\text { (menit) }\end{array}$ & $\begin{array}{c}\text { Motor } \\
\text { Servo } \\
\text { MG995 }\end{array}$ & Buzzer \\
\hline 1. & Mendeteksi & $40,21^{\circ}$ & 15 menit & $\begin{array}{c}\text { Berputar } \\
90^{\circ}\end{array}$ & Aktif \\
\hline 2. & Mendeteksi & $41,56^{\circ}$ & 30 menit & $\begin{array}{c}\text { Berputar } \\
90^{\circ}\end{array}$ & Aktif \\
\hline 3. & Mendeteksi & $42,88^{\circ}$ & 45 menit & $\begin{array}{c}\text { Berputar } \\
90^{\circ}\end{array}$ & Aktif \\
\hline
\end{tabular}

\subsection{Pengujian GSM SIM80L}

Pengujian GSM SIM800L V1 digunakan untuk mengetahui kinerja dari GSM Modul untuk dapat memberikan pesan secara jarak jauh dengan waktu yang singkat atau tanpa delay. Tegangan yang dibutuhkan oleh GSM SIM800L V1 ialah 3,3 V - 4,4 V [8], maka dari itu diperlukan Regulator LM2596 tegangan untuk memastikan tegangan pada GSM Modul stabil dan mendapatkan sinyal yang stabil juga. Regulator yang digunakan ialah DC to DC dan diatur tegangan output 4,3 V yang mana GSM Modul mendapatkan sinyal dan ditandai kedip led pada GSM Modul per 3 detik. Cara kerja dari GSM Modul memanfaatkan TX RX untuk saling mengirim dan menerima serial komunikasi yang akan digunakan dan dipasang terbalik pada lawan sehingga terjadi koneksi yang benar. GSM Modul memiliki pengaturan 
AT commands ialah infromasi perintah untuk komunikasi dengan serial port. Pengujian ini dilakukan dengan percobaan menyalakan dan mematikan led.

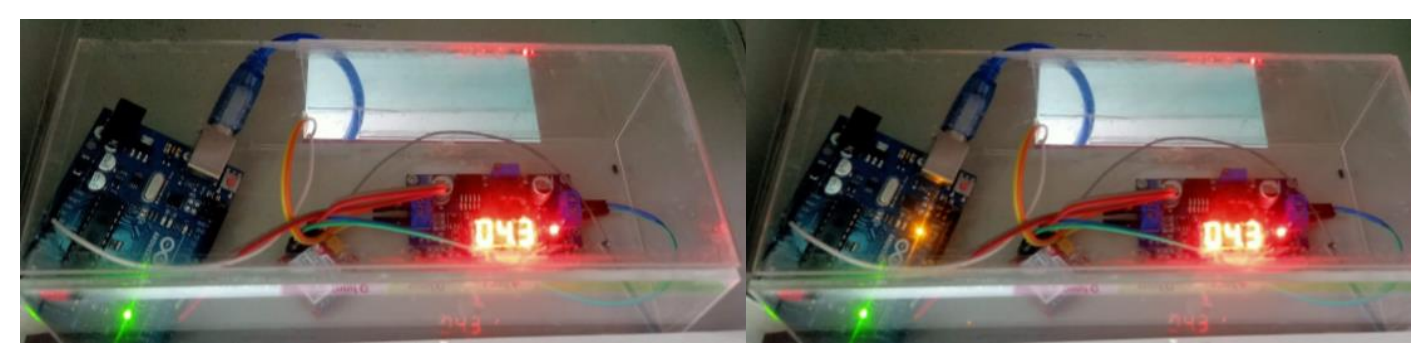

Gambar 7. Pengujian GSM SIM800L Led Mati dan Led Nyala

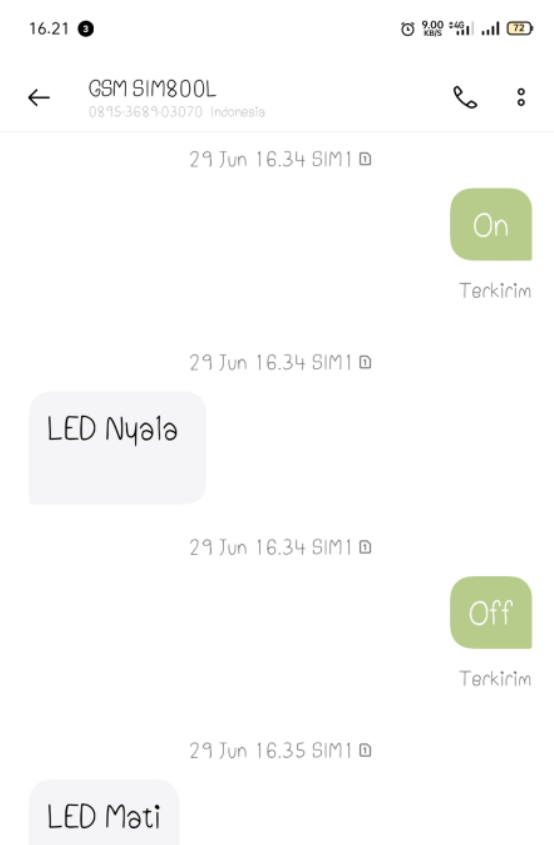

Gambar 8. Tampilan Telepon Seluler

Saat telepon seluler mengirimkan pesan "On" kepada perangkat maka GSM akan memberikan sinyal ke Arduino Uno untuk menyalakan led dan akan mengirimkan pesan balasan "LED Nyala" begitu pula ketika mengirimkan pesan "Off" ke perangkat maka akan mematikan led dan mengirimkan pesan balasan "Led Mati".

\subsection{Pengujian Keseluruhan Alat}

Pengujian keseluruhan alat digunakan untuk mengetahui kinerja alat dengan menggabungkan semua komponen yang telah diujikan sebelumnya. Pada saat pengujian alat dilakukan, semua komponen aktif karena mendapatkan sumber tegangan langsung. Kemudian sensor Inframerah KY-026, DS18B20, Motor Servo MG995 dan buzzer langsung aktif dan siap bekerja tetapi GSM SIM800L V1 setelah mendapatkan tegangan 4,3 V mencari sinyal terlebih dahulu untuk siap mengirim notifikasi ketika terjadi memungkinkan untuk mengirim. Setelah GSM Modul mendapatkan sinyal dengan led pada GSM Modul berkedip setiap 3 detik yang menandakan siap untuk digunakan maka sistem alat dapat bekerja dengan baik. Pertama sensor Inframerah KY-026 aktif dan led menyala yang berarti 
siap mendeteksi lalu sensor suhu DS18B20 untuk mengukur suhu didalam box panel, kemudian ketika terdapat api maka sensor Inframerah KY-026 mendeteksi yang ditandai dengan led 2 pada sensor dan mengaktifkan Motor Servo MG995 untuk menggerakan APAR juga buzzer yang membunyikan alarm peringatan dini untuk sekitar lokasi terdekat box panel. Kemudian kinerja sensor suhu DS18B20 sebagai monitoring suhu ketika terjadi "Overheat", maka dari itu sistem yang dilakukan oleh GSM SIM800L V1 akan mengirimkan notifikasi pesan saat terjadi overheat yaitu pada suhu $41^{\circ}$ kemudian ketika terdapat api yang terdeteksi oleh sensor Inframerah KY-026 akan mengirimkan notifikasi terjadinya kebakaran dan nilai suhu yang terdeteksi.
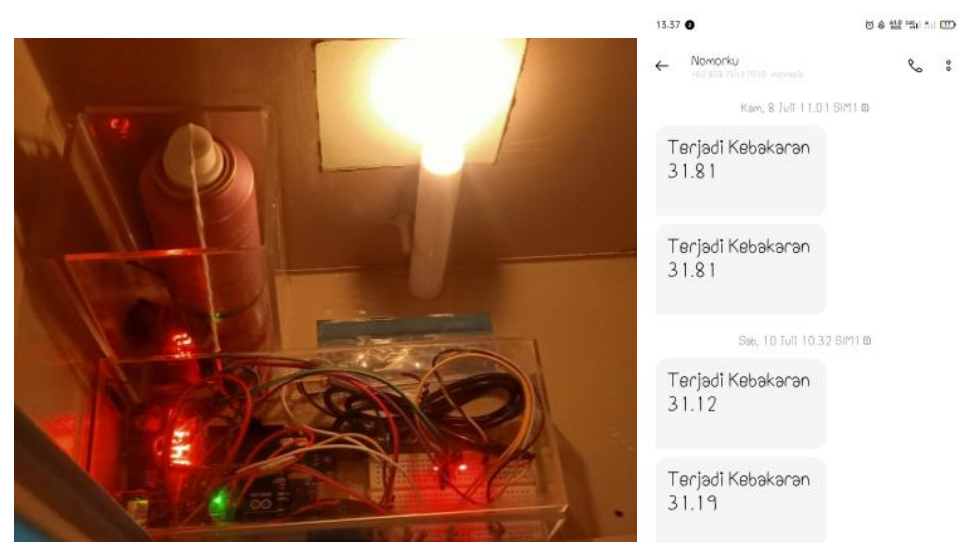

Gambar 9. Pengujian Keseluruhan Alat

Pada gambar diatas dapat diketahui bahwa pengunaan GSM SIM 800L V1 sebagai komunikasi berjalan dengan baik. percobaan ini dilakukan berulang kali dengan jarak yang telah ditentukan untuk digunakan sebagai perbandingan.

Tabel 4. Hasil Pengujian Keseluruhan Alat

\begin{tabular}{|c|c|c|c|}
\hline No. & $\begin{array}{c}\text { Jarak } \\
\text { (meter) }\end{array}$ & $\begin{array}{c}\text { Delay } \\
\text { (detik) }\end{array}$ & Keterangan \\
\hline 1. & $<10$ & 0 & Alat dapat bekerja \\
\hline 2. & 100 & 0 & Alat dapat bekerja \\
\hline 3. & 300 & 0 & Alat dapat bekerja \\
\hline 4. & 500 & 0 & Alat dapat bekerja \\
\hline 5. & 550 & 1 & Alat dapat bekerja \\
\hline 6. & 700 & 1 & Alat dapat bekerja \\
\hline 7. & 800 & 1 & Alat dapat bekerja \\
\hline 8. & 900 & 1 & Alat dapat bekerja \\
\hline 9. & 1000 & 1 & Alat dapat bekerja \\
\hline 10. & 1120 & 1 & Alat dapat bekerja \\
\hline
\end{tabular}

Setelah melakukan pengukuran dengan jarak 1210 meter, alat masih berfungsi untuk mengirimkan notifikasi sms kepada penerima. Pada dasarnya sistem komunikasi dengan GSM Modul dapat digunakan pada jarak yang sangat jauh dengan syarat wilayah tersebut terjangkau dengan jaringan GSM yang stabil. 


\section{KESIMPULAN DAN SARAN}

Rancang bangun sistem pemadam menghindari terjadinya kebakaran besar pada box panel kelistrikan dan dapat mempermudah memonitoring suhu agar mencegah overheat begitu juga dapatnya dilakukan komunikasi jarak jauh pada saat kebakaran terjadi pada box panel melalui telepon seluler GSM SIM800L V1 mencari sinyal untuk siap mengirimkan SMS pada telepon seluler. Sensor Inframerah KY-026 akan mendeteksi api kebakaran deteksi 160 lebih dan suhu DS18B20 mendeteksi suhu didalam box panel yang menandakan overheat pada saat $41^{\circ}$. Inframerah KY-026 ketika mendeteksi api kebakaran akan mengaktifkan Motor Servo MG995 untuk mengeluarkan cairan pemadam dan mengaktifkan buzzer sebagai peringatan dini bagi sekitar lokasi. Dengan bersamaan GSM SIM800L V1 akan mengirimkan SMS ke telepon seluler pada nomor tujuan yang telah ditentukan. Maupun ketika terjadi overheat, GSM SIM800L V1 akan mengirimkan notifikasi ke telepon seluler. Pada pengujian pengiriman pesan dapat sampai dengan jarak 516.000 meter bahkan lebih luas dengan syarat lokasi memiliki jaringan sinyal yang bagus.

Saran yang dapat diberikan untuk pengembangan penelitian selanjutnya adalah sistem pengukuran suhu dapat lebih akurat untuk menunjukan tingkat suhu yang tinggi pada api yang terdeteksi didalam box panel dan dengan waktu yang singkat sehingga menjadi lebih efisien dalam mendeteksi.

pengaplikasian secara langsung dengan peletakan komponen pada box panel yang sudah terisi instalasi listrik agar lebih spesifik pada penggambaran ilustrasi komponen dan menyesuaikan kondisi APAR yang akan digunakan di dalam box panel.

\section{UCAPAN TERIMAKASIH}

Dengan ini penulis mengucapkan terima kasih yang sebesar-besarnya kepada seluruh dosen, staf dan instruktur dalam lingkup S1 Teknik Elektro Institut Teknologi PLN serta kedua orang tua, rekan dan kerabat yang telah memberikan dukungan.

\section{DAFTAR PUSTAKA}

[1] Armando, Refky, R. P. (2019). Prototipe Perangkat Pendeteksi Api dan Suhu Pada Box Panel Kontrol Listrik Di Kapal. Teknik Elektro, Fakultas Teknik, Universitas Maritim Raja Ali Haji, 3(2252), 58-66.

[2] Alfalah, \& Widodo, T. S. (2009). Alat Pencegah Kebakaran Berbasis Mikrokontroler AT89851 Pada Box Panel Kontrol Listrik. Teknik Elektro, 1(1).

[3] Hakim, L., \& Halim, J. (2018). Peringatan Kebakaran Hutan Menggunakan Sensor Api , Suhu dan Asap. Seminar Nasional Teknologi Informasi Dan Komunikasi, 14, 2638.

[4] Nusyirwan, D., Ajay, A., \& Putra Perdana, P. P. (2019). Rancang Bangun Sistem Deteksi Kebakaran Pada Ruang Kelas Berbasis Mikrokontroller. Dinamika Rekayasa, 15(2), 95. https://doi.org/10.20884/1.dr.2019.15.2.274

[5] Sari, S. P., Candra, O., \& Asmi, J. (2020). Alat Pendeteksi Kebakaran Menggunakan SMS. 1(2), 251-254.

[6] Sasmoko, D., \& Mahendra, A. (2017). Rancang Bangun Sistem Pendeteksi Kebakaran Berbasis IoT Dan Sms Gateway Menggunakan Arduino. Simetris : Jurnal Teknik Mesin, Elektro Dan IImu Komputer, 8(2), 469. https://doi.org/10.24176/simet.v8i2.1316. 
[7] Apriyaningsih, M., Muid, A., \& Nurhasanah, N. (2017). Prototipe Sistem Pemadam Kebakaran Otomatis Berbasis Mikrokontroler Atmega328p. PRISMA FISIKA, 5(3), 106-110.

[8] SIMCom.(2013).Sim800L_Hardware_Design_V1.00.170.http://wiki.seeedstudio.com/images/4/46/SIM800L_Hardware_Design_V1.00.pdf

[9] Husada, H., \& Samsurizal, S. Sistem Pemantauan Temperatur dan Kelembaban Menggunakan Instrumentasi Virtual Sebagai Pendeteksi Dini Bahaya Kebakaran. TESLA: Jurnal Teknik Elektro, 21(2), 113-122.

[10] Sutyanegara, A. (2019). Rancang Bangun Prototype Sistem Pemantauan Kebocoran Pipa Landfill Gas (LFG) Pada Pltsa Berbasis Mikrokontroler Node Mcu Esp8266 Dengan Metode Internet Of Things (IOT). Repository Sekolah Tinggi Teknik PLN. 